\title{
Assessment of Combined Effect of Macrophomina phaseolina and Fusarium oxysporum on Disease Incidence of Sesame (Sesamum indicum L.)
}

\author{
B. Khamari ${ }^{1 *}$, S.K. Beura ${ }^{1}$, A. Sushree ${ }^{1}$ and S.P. Monalisa ${ }^{2}$ \\ ${ }^{1}$ Department of plant pathology, College of Agriculture, OUAT, Bhubaneswar, Odisha, India \\ ${ }^{2}$ Department of Seed Science and Technology, College of Agriculture, \\ OUAT, Bhubaneswar, Odisha, India \\ *Corresponding author
}

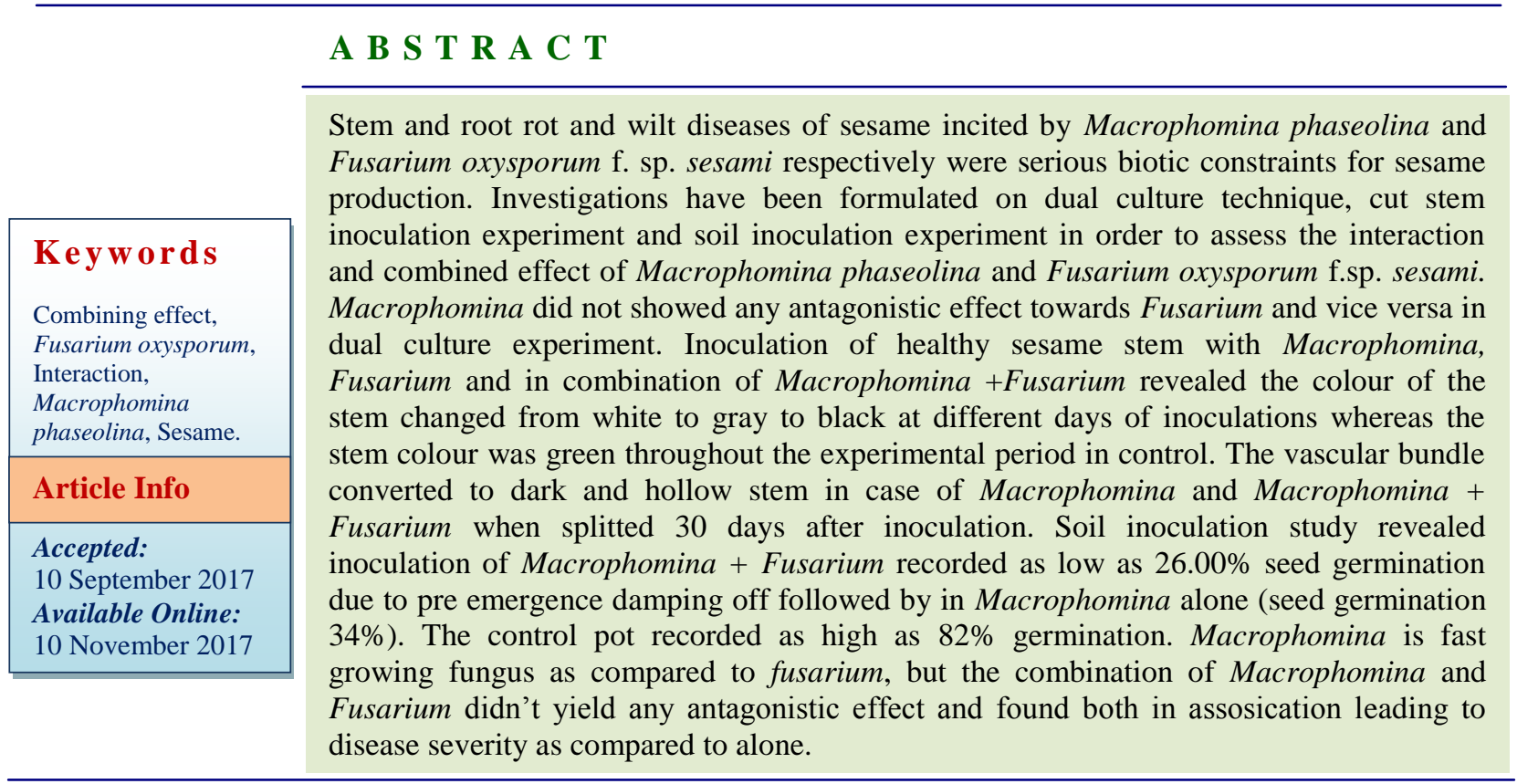

\section{Introduction}

Area and production of sesame is declining day by day in the traditional sesame growing areas due to severe biotic stresses such as Bacterial blight, Macrophomina stem rot, Phyllody, Fusarium wilt, Powdery mildew, Alternaria leaf spot and Cercospora leaf spot. Macrophomina phaseolina may cause heavy yield losses in sesame, if management is not proper. Variation of root rot disease incidence depends on the soil conditions and crop seasons. Wilt and root rot diseases of sesame caused by Fusarium oxysporum f. sp. sesami and Macrophomina phaseolina are serious biotic constraints for sesame production. These are most important and widespread soil and seed-borne diseases of sesame grown where the climate is relatively dry and warm. Both Macrophomina and Fusarium are found associated with each other in sesame causing stem rot, root rot and wilt all together leading to rapid dying of the plant. Under the above circumstances an investigation has been 
formulated to assess the synergistic or antagonistic relationship of Macrophomina and Fusarium under Bhubaneswar condition.

\section{Materials and Methods}

Macrophomina and Fusarium were isolated from the infected sesame plants and brought into pure culture following standard procedure of hyphal tip method.

Interaction study of Macrophomina and Fusarium in vitro

The interaction study between Macrophomina and Fusarium was done by dual culture technique keeping $5 \mathrm{~mm}$ mycelia disc of each pathogen at opposite side of the petriplates in triplicates. A set of individual test fungus was maintained as control. Observations were taken every day to see the interactions between them. A small tint of mycelia from interaction zone was taken in a slide and observed under microscope.

\section{In vitro study of disease complex}

In order to study the sole and combine effect on sesame stem, an in vitro experiment was undertaken. Two hundred $\mathrm{ml}$ potato dextrose broth was taken in $500 \mathrm{ml}$ conical flask. Two healthy sesame cut stem of $7.5 \mathrm{~mm}$ diameter with $10 \mathrm{~cm}$ length were kept in the flask and tightly plugged with non-absorbent cotton. Likewise 12 conical flasks were used for experiment. All the flasks were autoclaved.

After cooling, flask were inoculated with $6 \mathrm{~mm}$ disc of Macrophomina, then Fusarium in second, both Macrophomina + Fusarium in third, fourth flask was remained uninoculated which was served as control. Three replications were maintained. These flask were then kept undisturbed and observations were taken regularly at 2, 4, 6, 10 and 30 days after inoculation. After 30 days, the stems were taken out and splited. The conditions of vascular bundle were recorded.

\section{In vivo study of disease complex}

The experiment was conducted in plastic pots. Macrophomina phaseolina, Fusarium oxysporum and both Macrophomina phaseolina + Fusarium oxysporum previously multiplied in sand maize medium were inoculated into sterilized soil at the rate of $2 \mathrm{~g} / \mathrm{kg}$ of soil. One of the treatment was retained uninoculated which served as control. All the pots were sown with seed variety VRI-1 and kept in completely randomized design. Each treatment replicated five times. Daily observations were undertaken and germination, disease incidence as well as mortality were recorded. The data obtained were analysed statistically.

\section{Results and Discussion}

\section{Dual culture technique}

Both the pathogen grew and intermingled with each other. Fusarium did not show any antagonistic effect against Macrophomina and vice versa. It was also observed that, Macrophomina grew faster than Fusarium covering maximum portion of the plate. Both the pathogens were coexisted while observed under microscope.

\section{In vitro cut stem inoculation method}

The sesame stem cuttings were inoculated with Macrophomina, Fusarium and in combination and the observations were recorded at 2, 4, 6, 10 and 30 days after inoculation. The colour of the mycelium was white and there was superficial coverage over the medium. The incidence was low in Macrophomina and Fusarium and the incidence was moderate in combination after 2 days of inoculation. At 4 days after 
inoculation, the mycelium colour changes to grey, white and white + grey by Macrophomina, Fusarium and in Macrophomina + Fusarium respectively (Table 1).

The mycelium found to be grown upto half of the stem along with full coverage of the medium by Macrophomina and only coverage of the medium by the Fusarium without stem infection and both the combinations recorded full coverage of medium along with one fourth of the stem infection. Gradually the colour became dark grey covering total medium and the stem due to Macrophomina inoculation and creamy white in colour and covering total medium along with one fourth portion of the stem due to Fusarium and both combinations imparted grayish colour and covered full medium along with half portion of the stem after 6 days of inoculation. After 10 days of inoculation, the colour was found converted to black, creamy white and grey due to Macrophomina, Fusarium and combinations respectively covering the whole medium and stem by both the pathogen alone and in combination. After 30 days of inoculation, the inoculated stem characteristics were studied before splitting and after splitting the stem into two halves. The inoculated stem before splitting the bark was dark in colour with some black dot like growths on Macrophomina and the stem was rotten with presence of whitish mycelia growth due to Fusarium and grayish colour in combination of Macrophomina and Fusarium.

After splitting, the stem colour was charcoal black with hollow vascular bundle, white with rotten vascular bundle and grey with hollow vascular bundle found inoculated with Macrophomina, Fusarium and combinations respectively. The microsclerotia formation was observed in Macrophomina and Macrophomina + Fusarium combinations. However, in control (without inoculation by pathogen) the stem colour was green throughout the experimental period.

It is revealed from the inoculation study that inoculation by Macrophomina, Fusarium and combination of Macrophomina + Fusarium the colour of the stem changed from white to gray to black at different days of inoculations.

Plate.1 Interaction between Macrophomina phaseolina and Fusarium oxysporum in dual culture techniques. Plate.2 Cut stem inoculation experiment showing control, Macrophomina,

Fusarium, Macrophomina + Fusarium (from left to right)
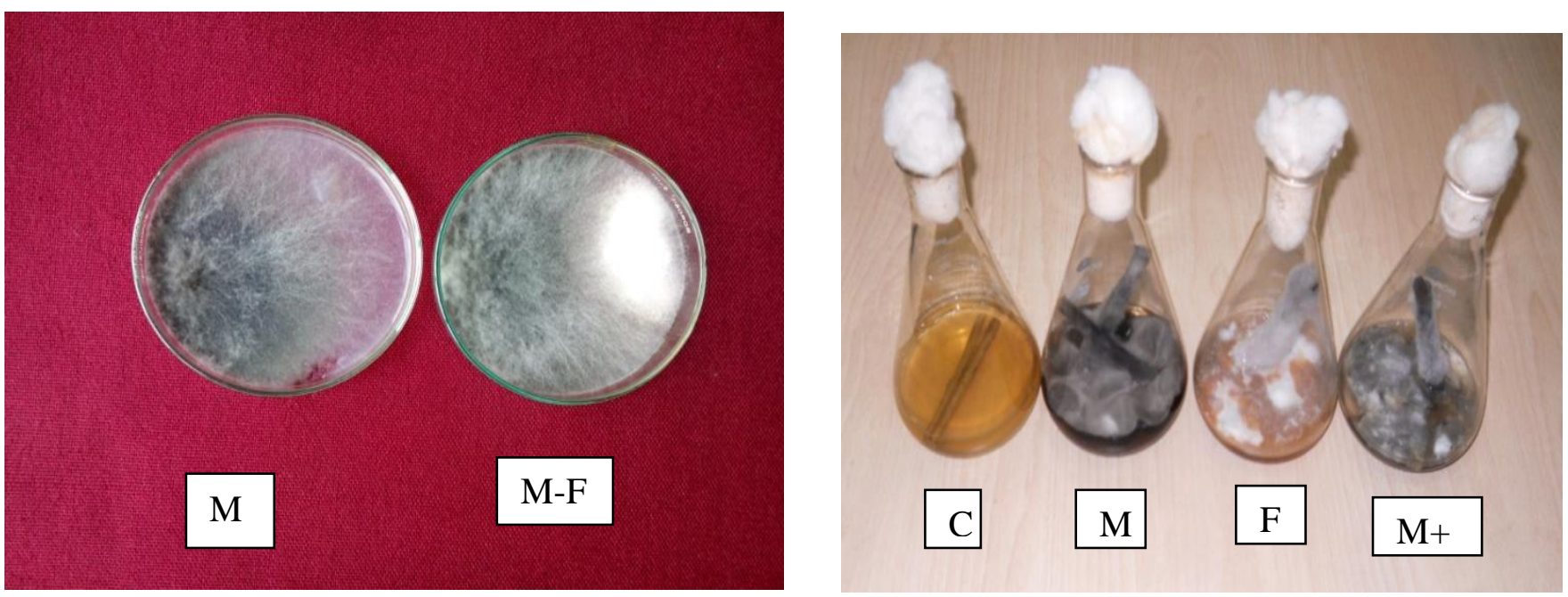
Table.1 Cultural characters of Macrophomina, Fusarium and their combinations at different days after inoculation

\begin{tabular}{|l|l|l|l|l|l|l|l|l|}
\hline Treatments & 2 DAI & 4 DAI & \multicolumn{2}{l|}{ 6DAI } & 10 DAI \\
\hline & Colour & Coverage & Colour & Coverage & Colour & Coverage & Colour & Coverage \\
\hline Macrophomina & White & Medium & Grey & $\begin{array}{l}\text { Medium } \\
+\quad \text { half } \\
\text { stem }\end{array}$ & $\begin{array}{l}\text { Dark } \\
\text { grey }\end{array}$ & $\begin{array}{l}\text { Medium } \\
+ \text { stem }\end{array}$ & Black & $\begin{array}{l}\text { Medium } \\
+ \text { stem }\end{array}$ \\
\hline $\begin{array}{l}\text { Fusarium } \\
\text { Macrophomina } \\
+ \text { Fusarium }\end{array}$ & White & Medium & White & Medium & $\begin{array}{l}\text { Cream } \\
\text { yhite }\end{array}$ & $\begin{array}{l}\text { Medium } \\
+1 / 4^{\text {th }} \\
\text { stem }\end{array}$ & $\begin{array}{l}\text { Cream } \\
\text { white }\end{array}$ & $\begin{array}{l}\text { Medium } \\
+ \text { stem }\end{array}$ \\
\hline Control & Green & - & $\begin{array}{l}\text { White+ } \\
\text { grey }\end{array}$ & $\begin{array}{l}\text { Medium } \\
+1 / 4^{\text {th }} \\
\text { stem }\end{array}$ & Grey & $\begin{array}{l}\text { Medium } \\
+1 / 2 \text { stem }\end{array}$ & Grey & $\begin{array}{l}\text { Medium } \\
+ \text { stem }\end{array}$ \\
\hline
\end{tabular}

\begin{tabular}{|c|c|c|c|c|c|c|}
\hline \multirow[t]{3}{*}{ Treatments } & \multicolumn{6}{|c|}{30 days after Inoculation } \\
\hline & \multicolumn{3}{|c|}{ Characteristics before splitting } & \multicolumn{3}{|c|}{ Characteristics after splitting } \\
\hline & $\begin{array}{l}\text { Colour of } \\
\text { medium }\end{array}$ & $\begin{array}{l}\text { Colour } \\
\text { of stem }\end{array}$ & Stem character & $\begin{array}{l}\text { Colour of } \\
\text { stem }\end{array}$ & $\begin{array}{l}\text { Stem } \\
\text { character }\end{array}$ & Microsclerotia \\
\hline Macrophomina & Black & Black & $\begin{array}{l}\text { Dark bark, fleshy, } \\
\text { black growth on it }\end{array}$ & Black & Hollow VB & Present \\
\hline Fusarium & $\begin{array}{l}\text { Creamy } \\
\text { white }\end{array}$ & $\begin{array}{l}\text { Creamy } \\
\text { white }\end{array}$ & $\begin{array}{l}\text { Rotten, fleshy bark, } \\
\text { whitish growth on it }\end{array}$ & White & Rotten VB & Absent \\
\hline $\begin{array}{l}\text { Macrophomina } \\
+ \text { Fusarium }\end{array}$ & Grey & Grey & Grey colour, fleshy & Grey & Hollow VB & Present \\
\hline Control & Normal & Green & Green and normal & $\begin{array}{l}\text { Light } \\
\text { yellow }\end{array}$ & Normal VB & Absent \\
\hline
\end{tabular}

Table.2 Effect of soil inoculation of Macrophomina, Fusarium and their combinations

\begin{tabular}{|l|l|l|l|}
\hline S. no & Treatments & Germination \% & $\begin{array}{l}\text { Pre emergence } \\
\text { damping off }\end{array}$ \\
\hline 1 & Macrophomina & $34(35.429)$ & $66(54.534)$ \\
\hline 2 & Fusarium & $52(46.311)$ & $48(43.653)$ \\
\hline 3 & Macrophomina + Fusarium & $26(27.586)$ & $74(62.385)$ \\
\hline 4 & Control & $82(65.332)$ & $18(24.632)$ \\
\hline $\mathrm{SE}(\mathrm{m})$ & & 5.020 & 5.022 \\
$\mathrm{CD}$ & & 15.179 & 15.186 \\
\hline
\end{tabular}

\section{In vivo disease complex study}

Under controlled condition, the soil inoculation study revealed inoculation of Macrophomina + Fusarium recorded as low as $26.00 \%$ seed germination due to pre emergence damping off corresponding to $72.00 \%$ followed by in Macrophomina alone (seed germination 34\%, pre emergence damping off 66\%) and Fusarium recording $52 \%$ seed germination with $48 \%$ pre emergence damping off. However, the control pots recorded $82 \%$ germination without inoculation with any pathogen. Since, the activity of Macrophomina was found quick in respect of dual culture technique, cut stem 
inoculation experiment and soil inoculation experiment as compared to Fusarium. It is proved that Macrophomina is fast growing fungus as compared to Fusarium. But the combination of Macrophomina and Fusarium didn't yield any antagonistic effect and found both in association leading to disease severity as compared to alone (Table 2).

The combined effect of Macrophomina and Fusarium was earlier studied by many workers in different crops. Mashooda et al., (2005) observed that M. phaseolina and Fusarium verticilloides were responsible for collar rot, seedling rot and other diseases in okra.

They also observed that inoculated seed caused reduced seed germination as well as pre- and post-emergence mortality. $M$. phaseolina + Fusarium oxysporum results amaximum reduction of growth of brinjal and controlled the fungal complex with carbendazim significantly (Haseeb and
Archana, 2009). These findings were in agreement to the present investigation.

\section{References}

Haseeb, A., and Archana, 2009. Pathogenic potential of Macrophomina phaseolina on Solanum melongena and management through integrated management. Ann. Pl. Protec. Sci. 17: 410-413.

Mashooda, B., S. Lokesh \& T.V. Kumar. 2005. Pathogenicity of Macrophomina phaseolina and Fusarium verticilloides in okra. Integ. Biosci. 9, 37-40.

Pandey R.N., N.M. Gohel and Pratik Jaisani. 2017. Management of Wilt and Root Rot of Chickpea caused by Fusarium oxysporum f. sp. ciceri and Macrophomina phaseolina through Seed Biopriming and Soil Application of Bio-Agents. Int.J.Curr.Microbiol. App.Sci. 6(5): 2516-2522.

\section{How to cite this article:}

Khamari, B., S.K. Beura, A. Sushree and Monalisa, S.P. 2017. Assessment of Combined Effect of Macrophomina phaseolina and Fusarium oxysporum on Disease Incidence of Sesame (Sesamum indicum L.). Int.J.Curr.Microbiol.App.Sci. 6(11): 1135-1139. doi: https://doi.org/10.20546/ijcmas.2017.611.135 